\title{
Comparative Study of Bunt Pathogen Resistance to the Effects of Fungicides in Callus Co-Cultures Triticum aestivum with Tilletia caries
}

\author{
L. G. Yarullina ${ }^{1,2}$, R. I. Kasimova1, B. R. Kuluev¹, 0. B. Surina1, L. M. Yarullina², \\ R. I. Ibragimov ${ }^{2}$ \\ ${ }^{1}$ Institute of Biochemistry and Genetics of Ufa Scientific Center of Russian Academy of Sciences, Ufa, Russia \\ ${ }^{2}$ Bashkir State University, Ufa, Russia \\ Email: kasimova007@gmail.com
}

Received 17 June 2014; revised 19 July 2014; accepted 20 August 2014

Copyright (C) 2014 by authors and Scientific Research Publishing Inc. This work is licensed under the Creative Commons Attribution International License (CC BY). http://creativecommons.org/licenses/by/4.0/

\section{(c) (i) Open Access}

\begin{abstract}
The morphophysiological and molecular-genetic parameters of $T$. caries isolates collected from various fields of Southern Urals agrocenoses have been analysed. Isolate 1 of wheat callus had a high growth rate in vitro even in the presence of $0.1 \mathrm{mg} / \mathrm{l}$ fungicide Baitan. Isolate 2 of wheat callus had a low growth rate whereas $0.1 \mathrm{mg} / 1$ Baitan significantly inhibited its growth. Comparison of nucleotide sequences of $18 \mathrm{~S}$ RNA gene of the two isolates showed high level of homology between them, but a large number of nucleotide substitutions have been found. The most characteristic excision was five nucleotides at position 461 of the isolate 2, compared with the isolate 1. Our results allow to assume that the environmental stress including high pesticide concentration may cause the resistance of $T$. caries pathogen to fungicides.
\end{abstract}

\section{Keywords}

Wheat, Tilletia caries, Calli, Triadimenol, 18S RNA, Resistance to Fungicides

\section{Introduction}

Smut fungi are placed among common harmful pathogens of crops whose control is an urgent task [1]. Upon the germination of infected grains it takes the bunt pathogen Tilletia caries (DC) Tull several days to penetrate the plant, mainly through coleoptile. Until ripening starts the grain disease develops without symptoms, and hyphae 
of the pathogen in the tissues of the host plant are extremely rarely occurring [2], thus impeding the investigation of the mechanisms of pathogen resistance.

Plant protection against bunt pathogen is mainly provided by chemical seed protectants. Until recently Carboxin fungicide - a fungi respiration inhibitor-has been used against smut diseases of plants [3] [4]. Subsequently azole fungicides or their mixtures have come to be widely used in protecting cereal crops from smut infection. Besides having a high fungicide activity, they also possess growth regulation properties (Derozol, Euro, Konkur KE) [5] [6].

Within the smallest biologically active concentrations these fungicides have been established to inhibit demethylation of lanosterol in position C-14. This is the first step in the transformation of lanosterol to ergosterol required for normal growth of most fungi [7] [8]. A number of other mechanisms of azole fungicides effects on fungal pathogens have been found, one of them being $\beta$-tubulin genes transformation in Ustilago maydis [9] [10].

An intensive use of chemical plant protection products leads to a change in the physiological properties of pathogens. For example, it is found that both the growth rate and the amount of generated spores in strains of fungi Bipolaris sp. and Septoria sp. cultured in increased concentrations of fungicides are lower than the growth rate of the wild type [10]-[12].

It is not a rare occasion that fungicides are used irrespective of the pathogens species composition distinctive for a specific region where crops are grown. This may lead to an unreasonably high pesticide load with a potential for the emergence of new resistant strains of pathogens [13].

For a convenient study of the bunt pathogen growth in wheat tissues we have created a co-culture of the pathogen $T$. caries and wheat calluses where the fungus develops for several weeks both on the surface and inside the callus [14]. Using the co-culture we have investigated some mechanisms of plant cell resistance to $T$. caries including the one under the influence of fungicide Baitan [15]. It is easy to study the genetic diversity of natural pathogen populations [16] using aerial mycelium of the fungus.

Territory of the Southern Ural in soil and climatic conditions is divided into 6 natural and agricultural areasNorthern forest-steppe, Northeast steppe, South steppe, the Ural steppe, Zauralskaya steppe and Mountain-forest area. Most favorable for the cultivation of spring wheat (Triticum aestivum L.) is south steppe. According to the National Plant Protection Station in South forest farms (gathering place isolate 1), since 2001, to protect crops, azole fungicides and benzimidazoles (raksil, barier-kolor, dospekh, vial, vintsit, baitan-universal) were mainly used, and North steppe zone (gathering place isolate 2) mainly used biological plant protection means.

In preliminary experiments, it was found that teliospores T. caries, isolated from the production of crops in South-steppe (isolate 1) germinated after 8 - 11 days after inoculation, and after 20 days the aerial mycelium covered $25 \%$ - $40 \%$ of the surface area of the callus cultured on medium Murashige and Skoog (MS). However, when biotrophic pathogen $T$. caries was cultured directly on MS medium it showed weak growth. At the same time, teliospores $T$. caries, isolated from wheat crop production in North forest steppe (isolate 2), germinated 5 days after inoculation of the callus, and after 8 - 9 days mycelium covered $30 \%-40 \%$ of the surface area of callus. Noteworthy is the fact that the spores of isolate 2 were actively grown not only in wheat calluses, but on MS medium. We have assumed that the properties of isolate 2 could be formed under the influence of the intensive use of fungicides to protect the crop production.

The task of research was a comparative study of the physiological and molecular-genetic parameters of isolates T. caries, collected from wheat plants from farms with high and low levels of fungal burden. It was assumed to examine the growth rate of isolates on wheat calli, cultured on MS medium + Baitan, their growth rate directly onto MS medium + Baitan as well as a comparison of the nucleotide sequences in the gene of the small subunit $18 \mathrm{~S}$.

\section{Materials and Methods}

As explants for callus tissue immature embryos of soft wheat cultivar Zhnitsa have been used. Some calluses were transplanted on the Murashige \& Skoog medium (MS) with added Baitan in concentrations of 0.1 and 1.0 $\mathrm{mg} / \mathrm{l}$. Baitan-systemic fungicide triazole series, aet triadimenol (Bayer CropScience, Germany). We have used the fungicide in these concentrations to study its influence on the growth of $T$. caries on wheat calluses [15]. The infectious material was: teliospores of sorus formed in the affected ear of wheat collected in the South Urals agrocenoses with different pesticide loads: South wooded steppe- the high (isolate 1) and North wooded- 
steppe- the low (isolate 2). Among micromycetes, pathogens of wheat smut diseases are the main fungi belonging to the order Ustilaginales, causing bunt. Bunt of wheat is caused by two pathogens: Tilletia caries (DC) Tul. (synonym-Tilletia tritici (Bjerk) Wint.) and Tilletia levis Kuchn. (synonym-Tilletia foetida (Wallr) Liro). Both species belong to the genus Tilletia Tul., family Tilletiaceae, order Ustilaginales [2]. Teliospores of T. caries are generally spherical, subspherical, sometimes oval shape, 14 - 18 microns in diameter. View T. caries is more specific for the northern regions of Russia, and the view T. levis-for the southern and south-eastern, forest-steppe zone of the European part of both species are found [17].

Teliospores (80 - 100 piece per callus) were spread on MS + Baitan medium but also on calluses cultured on MS + Baitan medium. Teliospores (80 - 100 per callus) was spread on MS medium + Baitan but also calli, cultured on MS medium + Baitan. Due to the fact that the temperature optimum for initiation of germination of teliospores $T$. caries is $8^{\circ} \mathrm{C}-12^{\circ} \mathrm{C}$ [18], the calli inoculated with the pathogen, and MS medium with spores deposited for 3 days were cultured at $8^{\circ}$ in controlled-environment growth chamber (MLR-350H, Sanyo, Japan) sealed in sterile flasks. Later temperature rose to $21^{\circ} \mathrm{C}$. Timing of spore germination and growth rate of aerial mycelium was estimated in 15 days from the start of the experiment. The wet mass was co-cultures of the fungus and the calluses were evaluated in 30 days after inoculation. Callus mass and co-cultures as well as the rate of growth of the fungus on calluses or in a culture without added fungicide were used as a control. 15 and 25 days after infection calluses were fixed for cytological analysis. The investigations were carried out on a microscope Imager M1.

DNA was isolated from the aerial mycelium collected from wheat calluses using a set of DNA-sorb (InterLabService, Russia). The quality and quantity of isolated preparations was determined by analytical electrophoresis in a $1 \%$ agarose gel. Agarose gel electrophoresis was carried out in Sub-Cell GT WIDE MINI (Bio-Rad, USA) device models. For the amplification of the gene of 18S RNA T. caries were used universal primers NS1 GTAGTCATATGCTTGTCTC, NS2 GGCTGCTGGCACCAGACTTGC,

NS3 GCAAGTCTGGTGCCAGCAGCC and NS4 CTTCCGTCAATTCCTTTAAG [18] [19]. "DNA technology" company production thermocyclers (Russia) were used for PCR. Sequencing was performed on an automatic sequencer "GenomeLab" (Beckman-Coulter, USA). Search homologous genes and alignment of nucleotide sequences was performed using the software MegAlign of package Lasergene (DNAstar, USA) and MegaBlast, available through the website http://www.ncbi.nlm.nih.gov.

In each variant of the experiment 5 calluses were used. Assays were repeated 3-fold. Statistical analysis was performed using computer programs StatSoft (Statistica 6.0).

\section{Results and Discussion}

The observation of the growth of the fungus T. caries on the calluses cultured on MS medium have showed that the spores of isolate 1 germinate on the average 5 days after inoculation, 15 days later the mycelium covered $83.6 \% \pm 2.8 \%$ callus surface (Figure 1(I-a), Table 1 and Table 2). Spore germination of isolate 2 occurred much later (on an average 10 days after application), and in 15 days the mycelium covered about $40 \%$ of the callus surface (Figure 1(II-a), Table 1 and Table 2).

The physiological differences between natural isolates of $T$. caries could be caused by sexual process which is the basis of their new forms and races formation [2]. At the same time, there is a possibility of new forms of the pathogen appearance under the influence of environmental conditions including intensive use of fungicides in agriculture [19]. In this regard, the study of the growth of isolates on wheat calluses in the presence of adverse factors-Baitan fungicide-was of considerable interest.

The introduction of callus $0.1 \mathrm{mg} / \mathrm{l}$ of Baitan to the culture medium delayed the germination of spore isolate 2 approximately to 10 days (Table 1). The expansion rate of this isolate on callus also decreased: 15 days after germination of spores the fungus mycelium covered about $20 \%$ of the calluses surface (Figure 1(II-b), Table 2). Adding of Baitan with concentration $1 \mathrm{mg} / \mathrm{l}$ in MS medium resulted in complete inhibition of spore germination of fungus isolate 2 T. caries (Figure 1(II-c)). However, the introduction to the culture medium of $0.1 \mathrm{mg} / \mathrm{lof}$ Baitan did not influence the rate of spore germination and growth of isolate 1 (Figure 1(I-b), Table 1 and Table 2). A reduced growth rate of the isolates on calluses was observed only when medium Baitan at a concentration $1.0 \mathrm{mg} / \mathrm{l}$ was added to the culture (Figure 1(I-c)). In this variant of the experiment, an increase of spore germination period on the average to 8 days was also observed.

The evaluation of wet weight infected callus confirmed different growth rates of isolates $T$. caries on the under the action of fungicide. The data in Table 3 show that under the action of 0.1 and $1.0 \mathrm{mg} / \mathrm{l}$ of Baitan the 

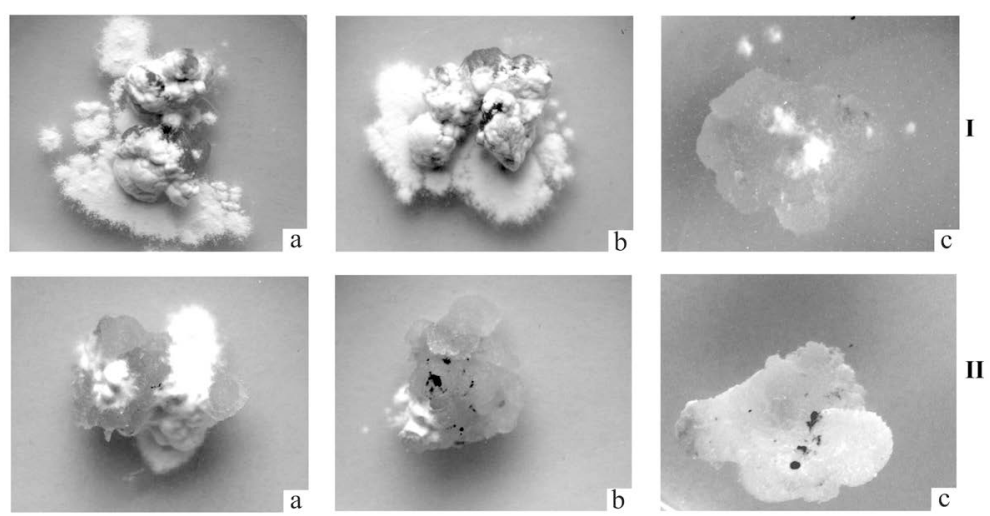

Figure 1. Intensity of development of isolates 1 (I) and 2 (II) of T. caries in co-culture with wheat calluses on MS medium. 15 days after inoculation. aMS medium; b-MS medium + $0.1 \mathrm{mg} / \mathrm{l}$ Baitan; c-MS medium $+1.0 \mathrm{mg} / \mathrm{l}$ Baitan.

Table 1. Influence of Baitan on the rate of spore germination of T. caries (d) on wheat calluses on MS medium.

\begin{tabular}{ccccc}
\hline \multirow{2}{*}{ Variant } & \multicolumn{2}{c}{ Calluses, $\mathrm{d}$} & \multicolumn{2}{c}{ MS medium, $\mathrm{d}$} \\
\cline { 2 - 4 } & Isolate 1 & Isolate 2 & Isolate 1 & Isolate 2 \\
\hline Control & $5.1 \pm 0.2$ & $10.5 \pm 0.2^{*}$ & $5.0 \pm 0.1$ & $10.5 \pm 0.1^{*}$ \\
Baitan $0.1 \mathrm{mg} / \mathrm{l}$ & $6.4 \pm 0.3$ & $20.4 \pm 0.3^{* *}$ & $5.2 \pm 0.3$ & $21.0 \pm 0.5^{* *}$ \\
Baitan $1.0 \mathrm{mg} / \mathrm{l}$ & $8.0 \pm 0.5^{* *}$ & No germination & $9.3 \pm 0.5^{* *}$ & No germination \\
\hline
\end{tabular}

Note to Tables $1-3 .{ }^{*}$ - The differences were significant at $\mathrm{p}<0.05$ in relation to isolate $1,{ }^{* *}$ — compared to the corresponding control.

Table 2. Influence of Baitan on the surface area of callus, covered with mycelium $T$. caries (\%) 15 days after inoculation.

\begin{tabular}{ccc}
\hline Variant & Isolate 1 & Isolate 2 \\
\hline Control & $83.6 \pm 2.8$ & $38.3 \pm 1.6^{*}$ \\
Baitan $0.1 \mathrm{mg} / \mathrm{l}$ & $82.3 \pm 3.4$ & $21.0 \pm 1.0^{* *}$ \\
Baitan $1.0 \mathrm{mg} / \mathrm{l}$ & $17.8 \pm 0.8^{* *}$ & No mycelium \\
\hline
\end{tabular}

Table 3. Influence of Baitan on crude callus weight (mg), infected by isolates of $T$. caries 30 days after inoculation.

\begin{tabular}{cccc}
\hline Variant & Uninfected calluses & Calluses infected by isolate 1 & Calluses infected by isolate 2 \\
\hline Control & $132 \pm 7$ & $154 \pm 9$ & $145 \pm 8$ \\
Baitan $0.1 \mathrm{mg} / \mathrm{l}$ & $124 \pm 8$ & $148 \pm 10$ & $127 \pm 10^{*}$ \\
Baitan $1.0 \mathrm{mg} / \mathrm{l}$ & $115 \pm 9$ & $137 \pm 10$ & $117 \pm 9^{*}$ \\
\hline
\end{tabular}

Note. Initial weight of calluses was $106 \pm 5 \mathrm{mg}$.

values of this parameter in isolate 2 were lesser than in the variant with isolate 1 .

In the experiments isolate spores were applied not only on the calluses but also on MS medium supplemented with Baitan. It was found that isolate spores germinated on medium without (control) or with fungicide just as long as in the parallel experiments on wheat calluses (Table 1). Figure 1 shows that in the control the growth rate of isolate 2 on medium surface was weak in comparison with isolate 1 . The growth rate of isolate 1 de- 
creased in the presence of culture medium $1.0 \mathrm{mg} / \mathrm{l}$ of Baitan (Figure 1(I-c)). Thus, our observations have revealed different growth rate of the isolates of $T$. caries in the presence of the fungicide Baitan.

Due to weak growth of isolate 2 on MS medium for further studies we used aerial mycelium of isolates growing on wheat calluses. It was observed that the aerial mycelium of isolate 1 could be easily separated from the callus tissue whereas isolate 2 mycelium grew into callus. The analysis of calluses sections showed that in the variant with calluses infected with isolate 1 hyphae were sporadic even 25 days after inoculation (Figure 2(a)) but numerous hyphae of isolates 2 could be seen in callus intercellular spaces already 15 days after inoculation (Figure 2(b)), this confirming our earlier observations [14]. These observations explain the differences between isolates in the degree of coupling of interstitial mycelium and callus tissue. Thus, isolate 1 was characterized by rapid growth on the surface of the callus and weak growth inside the callus.

Since isolate 1 was identified as having properties uncommon for Tilletia sp., we carried out a molecular genetic analysis of the samples. Since full genomes of this group of fungi are not sequenced both sites of the small subunit 18S RNA gene were amplified using universal primers NS1/NS2 and NS3/NS4. The amplicon dimensions coincided with the theoretically expected and amounted to 555 bp and 597 bp respectively (Figure 3(a)).

For comparison, amplicons NS1/NS2 and NS3/NS4 of isolate 2 of T. caries were obtained (Figure 3(b)). Later 4 target amplicons were cleaned with the help of the kit of Cytokine firm (Russia) and their nucleotide sequences were determined. The search for similar nucleotide sequences using the program MegaBlast showed homology of allocated amplicon sites of the small subunit gene 18S RNA Tilletia caries (U00972.1), Tilletia goloskokovii (DQ832247.1), Tilletia controversa (DQ832245.1) and Tilletia iowensis (DQ832252.1) which confirms the identity of isolate 1 with the Tilletia sp. With the program MegAlign alignment of nucleotide sequences of the amplicons NS1/NS2 isolate 1 (JQ955604) and 2 (JQ955605) was made. The comparison of the nucleotide sequences of these isolates have shown a high level of homology between them but single nucleotide

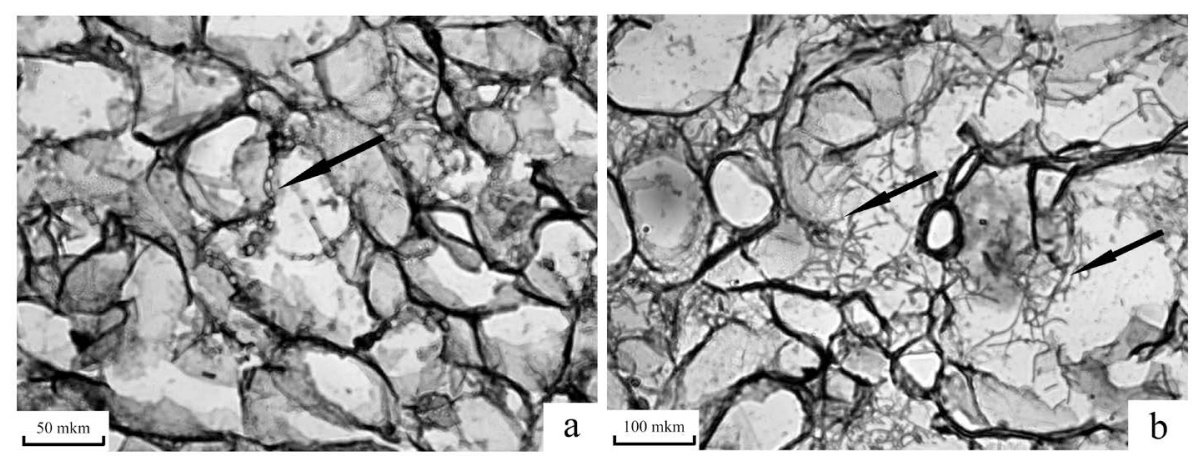

Figure 2. Hyphae of $T$. caries in wheat callus 25 (a) and 15 (b) days after inoculation. a-isolate 1 ; b-isolate 2 .

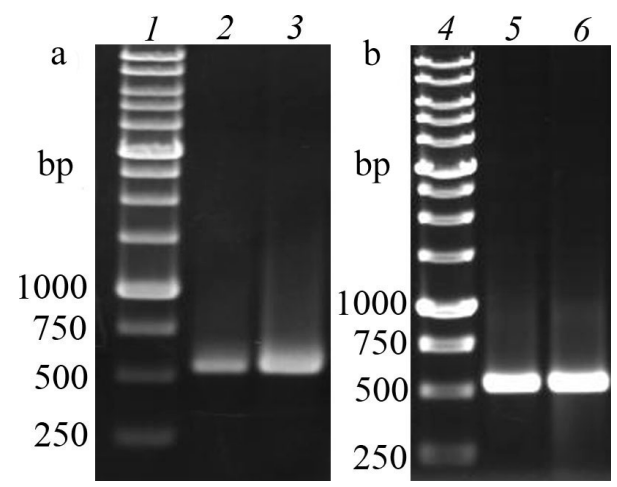

Figure 3. Electrophoretogram of PCR 18S RNA gene site of isolates 1 (a) and 2 (b) of T. caries. 1 and 4-molecular weight marker (SibEnzyme, Russia). 2 -amplicon NS1/NS2 of isolate 1 of T. caries. 3-amplicon NS3/NS4 of isolate 1 of $T$. caries. 4-amplicon NS1/NS2 of isolate 2 of $T$. caries. 5 - amplicon NS3/NS4 of isolate 2 of $T$. caries. 
substitutions have been found as well. In the future for the identification of T. caries isolates we plan to use universal primers ITS1/ITS2 and ITS3/ITS4 [20], which enable to amplify more variable regions of rRNA related to intergenic spacer.

Thus, we identified morphological, physiological and genetic differences between natural isolates of $T$. caries, collected from wheat plants of the Southern Urals agrocenosises with different pesticide loads. Differences concerned the timing of spore germination, mycelial growth rate on wheat calluses cultured on MS medium and MS + Baitan, as well as the rate of growth of isolates on medium MS and MS + Baitan. Isolates also differed in the intensity of development of mycelium in wheat calluses and the presence of single nucleotide substitutions in the gene for the small subunit $18 \mathrm{~S}$.

The data obtained suggest that the effect of environmentally adverse factors on the population of T. caries, including pesticides, may lead to the appearance of the fungus forms with greater fungicide resistance.

\section{Acknowledgements}

This research was financial supported by the Russian Foundation for Basic Research and Russian Education and Science Ministry (State registration No. 01201456414).

\section{References}

[1] Gici, U., Chet, I. and Gullino, M.L. (2009) Recent Development in Management of Plant Diseases. Springer, 392 p.

[2] Karatigin, I.V. (1981) Smut Fungi (Ontogenesis and Phylogenesis). Nauka, Leningrad, 216 p.

[3] Keon, J.P.R., White, G.A. and Hargreaves, J.A. (1991) Isolation, Characterization and Sequence of a Gene Conferring Resistance to the Systemic Fungicide Carboxin from the Maize Smut Pathogen Ustilago maydis. Current Genetics, 19, 475-481. http://dx.doi.org/10.1007/BF00312739

[4] Orth, A.B., Rzhetskaya, M., Pell, E.J. and Tien, M. (1995) A Serine Protein Kinase Confers Fungicide Resistance in the Phytopathogenic Fungus Ustilago maydis. Appl. Environ. Microbiol, 61, 2341-2345.

[5] Tuna, A.L. (2012) Comparative Activities of Triadimefon, Thidiazuron, and Chlorocholine Chloride as Salinity Stress Protectants in Maize (Zea mays L.) plant. Fresenius Environmental Bulletin, 21, 1598-1608.

[6] Fletcher, R.A. and Hofstra, G. (1987) Triasoles as Plant Stress Protectants. Highlights of Agricultural Research, 10, 12-14.

[7] Mysyakina, I.S. and Funtikova, N.S. (2007) The Role of Sterols in Morphogenetic Processes and Dimorphism in Fungi. Mikrobiologiya, 76, 1-13.

[8] Garcia, P.C., Rivero, R.V., Ruiz, J.M. and Romero, L. (2001) The Role of Fungicides in the Physiology of Higher Plants: Implications for Defense Responses. The Botanical Review, 69, 162-172. http://dx.doi.org/10.1663/0006-8101(2003)069[0162:TROFIT]2.0.CO;2

[9] Markoglou, A.N. and Ziogas, B.N. (2002) Genetic Control of Resistance to the Piperidine Fungicide Piperalin in Ustilago maydis. European Journal of Plant Pathology, 108, 21-30. http://dx.doi.org/10.1023/A:1013972914944

[10] Weber, I., Abmann, D., Thines, E. and Steinberg, G. (2006) Polar Localizing Class V Myosin Synthases Are Essential during Early Plant Infection in the Plant Pathogenic Fungus Ustilago maydis. Plant Cell, 18, 225-242. http://dx.doi.org/10.1105/tpc.105.037341

[11] Annamalai, P. and Lalithakumari, D. (1992) Development of Resistance of Bipolaris oryzae against Edifenphos. Mycological Research, 92, 454-460. http://dx.doi.org/10.1016/S0953-7562(09)81090-3

[12] Troshina, N.B., Isaev, R.F., Yakhin, I.A. and Yakhin, O.I. (1998) Influence of Environmental Factors on the Growth and Development of Resistant to Baitan Strain of Fusarium graminearum and Septoria nodorum. Mikologia i Fitopatologia, 32, 58-62.

[13] Palani, P.V. and Lalithakumari, D. (1999) Resistance of Venturia inaequalis to the Sterol Biosynthesis-Inhibiting Fungicide, Penconazole [1-(2-(2,4-dichlorophenyl)pentyl)-1H-1,2,4-triazole]. Mycological Research, 103, 1157-1164.

[14] Troshina, N.B., Glukhen’kova, M.V., Maksimov, I.V., Surina, O.B. and Khairullin, R.M. (2000) Morphological Analysis of the Growth and Development of Tilletia caries (DC.) Tul. on Wheat Calluses. Mikologia i Fitopatologia, 34, 48-50.

[15] Troshina, N.B., Yarullina, L.G., Surina, O.B. and Maksimov, I.V. (2006) Inducers of Plant Resistance and Reactive Oxygen Species. III. Influence Bisol 2 and Baitan on Morphogenesis and Cell Protective Response of Wheat Calluses Infected Smut Pathogen. Citologia, 48, 495-499.

[16] Martinez-Espinoza, A.D., Garcia-Pedrajas, M.D. and Gold, S.E. (2002) The Ustilaginales as Plant Pests and Model Systems. Fungal Genetics and Biology, 35, 1-20. http://dx.doi.org/10.1006/fgbi.2001.1301 
[17] Krivchenko, V.I. (1984) Resistance to Pathogens of Cereal Smut Diseases. Kolos, Moscow, 304 p.

[18] Borgen, A. (2004) Organic Seed Treatment to Control Common Bunt (Tilletia tritici) in Wheat. Seed Testing International, 128, 8-9.

[19] Rupukhova, N.V. (2005) Environmental Protection Aspects of Winter Wheat Dwarf Bunt on Leached Chernozem of the Stavropol Territory. Candidate of Biology Science Thesis, Stavropol.

[20] Gargas, A. and Taylor, J.W. (1992) Polymerase Chain Reaction (PCR) Primers for Amplifying and Sequencing $18 S$ rDNA from Lichenized Fungi. Mycologia, 84, 589-592. http://dx.doi.org/10.2307/3760327 
Scientific Research Publishing (SCIRP) is one of the largest Open Access journal publishers. It is currently publishing more than 200 open access, online, peer-reviewed journals covering a wide range of academic disciplines. SCIRP serves the worldwide academic communities and contributes to the progress and application of science with its publication.

Other selected journals from SCIRP are listed as below. Submit your manuscript to us via either submit@scirp.org or Online Submission Portal.
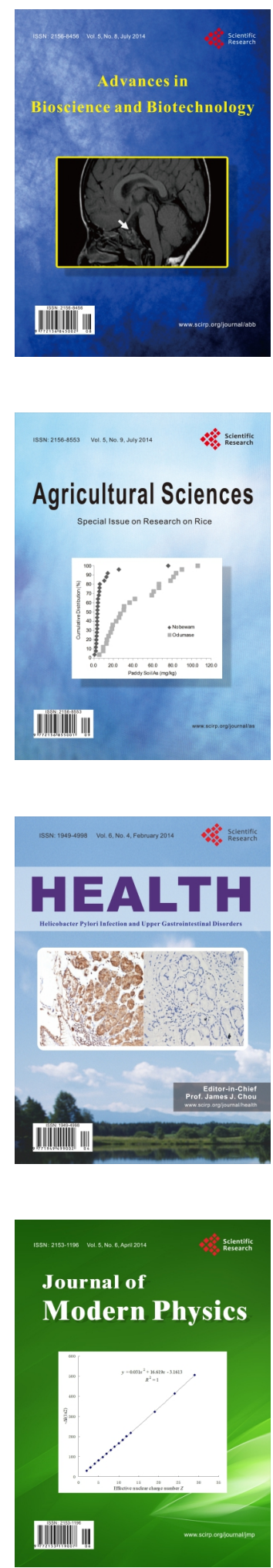
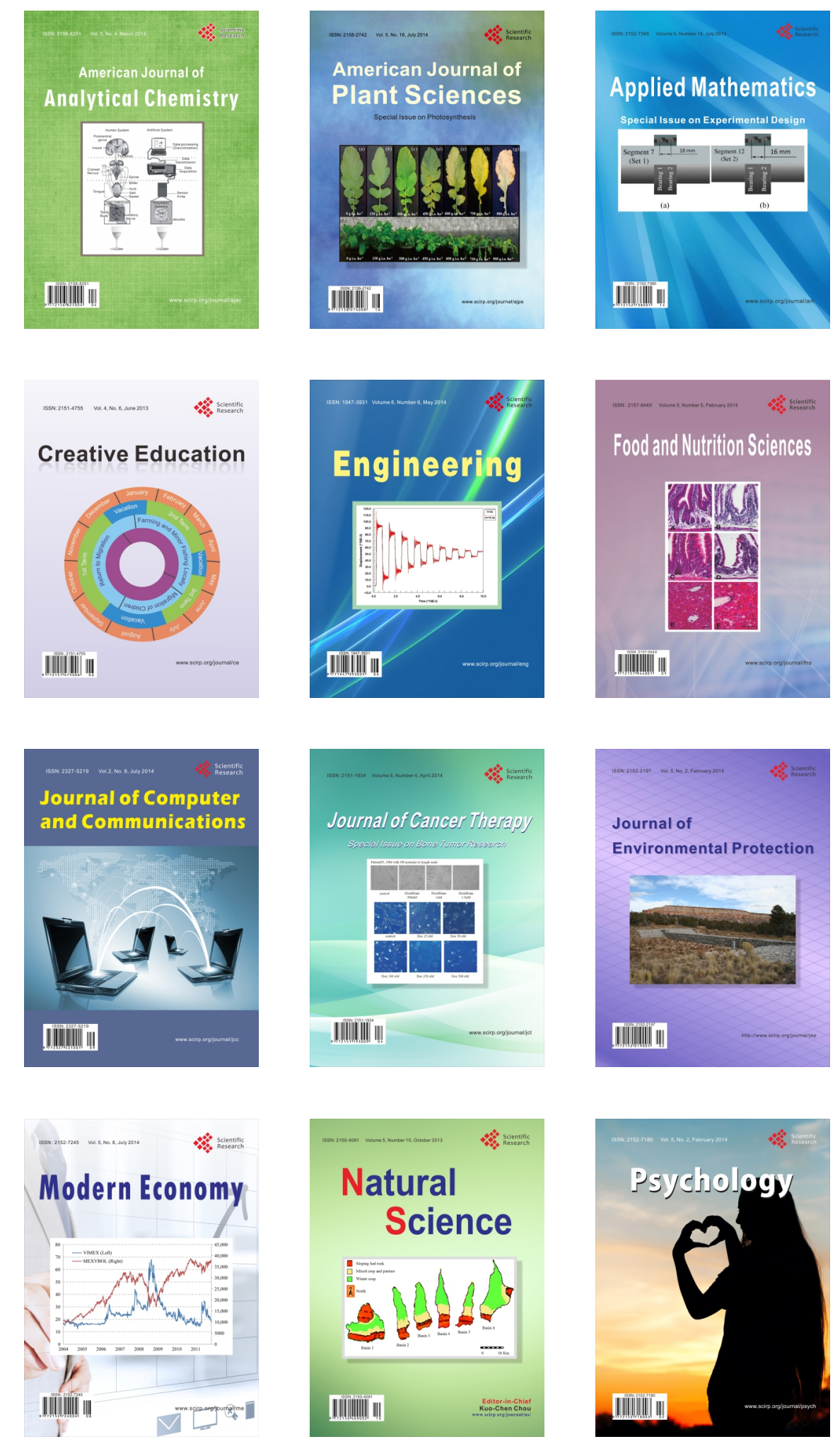